\title{
MANFAAT DOKUMENTASI DALAM MEMBERIKAN ASUHAN \\ KEPERAWATAN DI RUMAH SAKIT
}

Hanita Grace Sagala hanitagrace10@gmail.com

\begin{abstract}
ABSTRAK
Pelayanan keperawatan profesional yang berdasarkan ilmu pengetahuan mempunyai proses keperawatan yaitu suatu asuhan keperawatan sebagai metode ilmiah penyelesaian masalah keperawatan pasien untuk meningkatkan outcome pasien yang harus didokumentasikan. Pendokumentasian asuhan keperawatan dapat digunakan sebagai tanggung jawab dan tanggung gugat dari berbagai kemungkinan masalah yang dialami oleh pasien atau klien baik masalah kepuasan maupun ketidak puasan terhadap pelayanan kesehatan yang diberikan. Tanpa dokumentasi keperawatan maka semua implementasi keperawatan yang telah dilaksanakan oleh perawat tidak mempunyai makna dalam hal tanggung jawab dan tanggung gugat. Pedokumentasian asuhan keperawatan yang tepat waktu, akurat dan lengkap tidak hanya penting untuk melindungi perawat tetapi penting juga untuk membantu pasien atau klien mendapat asuhan keperawatan yang lebih baik.
\end{abstract}

Kata kunci : Asuhan Keperawatan, Dokumentasi, layanan kesehatan perawat.

\section{LATAR BELAKANG}

Dokumentasi adalah catatan yang dapat dibuktikan atau dapat menjadi bukti secara hukum. Dokumentasi keperawatan merupakan bagian dari pelaksanaan asuhan keperawatan yang menggunakan pendekatan proses keperawatan yang memilliki nilai hukum yang sangat penting. Tanpa dokumentasi keperawatan maka semua implementasi keperawatan yang telah dilaksanakan oleh perawat tidak mempunyai makna dalam hal tanggung jawab dan tanggung gugat. Dokumentasi keperawatan dapat dikatakan sebagai "pegangan" bagi perawat dalam mempertanggung jawabkan dan membuktikan pekerjaannya. Oleh karena itu ada berbagai aturan dan kaidah yang harus ditaati oleh setiap perawat dalam Melakukan pendokumentasian keperawatan.

Dengan proses keperawatan, rasa tanggung jawab dan tanggung gugat bagi perawat itu dapat dimiliki dan dapat digunakan dalam tindakan-tindakan yang merugikan atau menghindari tindakan yang legal. Semua tatanan perawatan kesehatan secara hukum perlu mencatat 
observasi keperawatan, perawatan yang diberikan, dan respons pasien.

Dokumentasi

keperawatan

merupakan bukti otentik yang dituliskan dalam format yang telah disediakan dan harus disertai dengan pemberian " tanda tangan" dan nama perawat serta harus menyatu dengan status / rekam medik pasien. Dalam pelaksanaan asuhan keperawatan pada pasien, setiap langkah dari proses keperawatan memerlukan pendokumentasian mulai dari tahap pengkajian, penentuan diagnosa keperawatan, intervensi, implementasi dan evaluasi keperawatan harus didokumentasikan.

Peran perawat sebagaimana kita ketahui adalah salah satunya dokumentasi sebagai pertanggungjawaban keperawatan, Akan tetapi akhir-akhir ini tanggung jawab perawat tehadap dokumentasi sudah berubah, Akibatnya, isi dan fokus dari dokumentasi telah dimodifikasi. Oleh karena perubahan tersebut ,maka perawat perlu menyusun suatu model dokumentasi yang baru, lebih efisien dan lebih bermakna dalam pencatatan dan penyimpanannya.

Perawat memerlukan keterampilan dalam mencatat proses keperawatan, Pencatatan proses keperawatan merupakan metode yang tepat untuk pengambilan keputusanyangsistematis, problemasolving dan riset lebih lanjut, format proses keperawatan merupakan kerangka atau dasar keputusan dan tindakan termasuk juga pencatatan hasil berfikir dan tindakan keperawatan. Dokumentasi adalah bagian integral proses, bukan sesuatu yang berbeda dari metode problema-solving. Dokumentasi proses keperawatan mencakuP pengkajian, identifikasi masalah, perencanaan, tindakan, Perawat kemudian mengobservasi dan mengevaluasi respon klien terhadap tindakan yang diberikan dan mengkomunikasikan informasi tersebut kepada tenaga kesehatan lainnya.

\section{TUJUAN}

Tujuan dibuatnya kajian ini adalah untuk menambah wawasan kepada pembaca tentang dokumentasi asuhan keperawatan.

\section{METODE}

Metode dalam penulisan ini dilakukan dengan mengumpulkan data dari buku, jurnal, dan thesis dan e-book, kemudian melakukan analisis secara mendalam terkait topik yang dibahas, serta bersifat subjektif yaitu proses penulisan yang lebih fokus pada landasan teori. Dan melakukan analisis buku dan e-jurnal yang relevan dan berfokus kepada pengaplikasian berfikir kritis dalam mengelola informasi dan komunikasi keperawatan. Adapun ejurnal yang digunakan ini adalah dengan menggunakan google dengan memasukkan 
kata kunci “ Konsep Dasar K3”. Jurnal yang digunakan adalah jurnal yang diterbitkan 8 tahun terakhir. Adapun referensi akan dicantumkan dalam penulisan ini dengan jelas terdapat pada daftar pustaka pada bagian akhir penulis.

\section{HASIL}

\section{Manfaat Dokumentasi Keperawatan}

1.Hukum Semua catatan informasi tentang klien merupakan dokumentasi resmi dan bernilai hukum, Bila terjadi suatu masalah (minconduct) yang berhubungan dengan profesi keperawatan, dimana perawat sebagai pemberi jasa dan klien sebagai pengguna jasa, maka dokumentasi diperlukan sewaktu-waktu, Dokumentasi tersebut dapat dipergunakan sebagai barang bukti di pengadilan, Oleh karena itu, data-data harus diidentifikasi secara lengkap, jelas, obyektif dan ditandatangani oleh tenaga kesehatan (perawat), tanggal dan perlunya dihindari adanya penulisan yang dapat menimbulkan interprestasi yangsalah.

2.Jaminan Mutu (Kualitas Pelayanan ) Pencatatan data klien yang lengkap dan akurat, akan member kemudahan bagi perawat dalam membantu menyelesaikan masalah klien dan untuk mengetahui sejauh mana masalah klien dapat teratasi dan seberapa jauh masalah baru dapat diidentifikasi dan dimonitor melalui catatan yang akurat, Hal ini akan membantu meningkatkan mutu pelayanan keparawatan.

3.Komunikasi Dokumentasi keadaan klien merupakan alat "perekam" terhadap masalah yang berkaitan dengan klien, Perawat atau tenaga kesehatan lain akan bisa melihat catatan yang ada sebagai alat komunikasi yang dijadikan pedoman dalam memberikan asuhan keperawatan. 4.Keuangan Dokumentasi dapat bernilai keuangan, Semua tindakan keperawatan yang belum, sedang dan telah diberikan dicatat dengan lengkap yang dapat dipergunakan sebagai acuan atau pertimbangan dalam biaya keperawatan bagiklien.

5.Pendidikan Dokumentasi keperawatan mempunyai nilai pendidikan ,karena isinya menyangkut kronologis dari kegiatan asuhan keperawatan yang dapat dipergunakan sebagai bahan atau referensi pembelajaran bagi siswa atau profesi keperawatan.

6.Penelitian Dokumentasi keperawatan mempunyai nilai penelitian. Data yang terdapat didalamnya mengandung informasi yang dapat dijadikan sebagai bagian atau obyek riset dan pengembangan profesikeperawatan.

7.Akreditasi Melalui dokumentasi keperawatan akan dapat dilihat sejauh mana peran dan fungsi perawat dalam memberikan asuhan keperawatan kepada klien. Dengan demikian akan dapat 
diambil kesimpulan tingkat keberhasilan pemberian asuhan keperawatan yang diberikan, guna pembinaan dan pengembangan lebih lanjut. Hal ini selain bermanfaat bagi peningkatan mutu sendiri, juga bagi individu perawat dalam mencapi tingkat kepangkatan yang lebih tinggi.

\section{PEMBAHASAN}

Dokumentasi adalah segala sesuatu yang tercetak atau tertulis yang dapat di andalkan sebagai catatan bukti bagi individu yang berwenang (Potter,2006). Dokumentasi keperawatan adalah bukti pencatatan dan pelaporan yang dimiliki perawat dalam catatan perawatan yang berguna untuk kepentingan klien, perawat dan tim kesehatan dalam memberikan pelayanan kesehatan dengan dasar data yang akurat dan lengkap secara tertulis sebagai tanggung jawab perawat (Wahid \& Suprapto,2012).

Tujuan pendokumentasian asuhan keperawatan adalah sebagai alat komunikasi antara klien, keluarga, tim perawat dan tim kesehatan lain sehingga terbentuk komunikasi yang baik dalam perawatan klien, sebagai tanggung jawab dan tanggung gugat perlindungan klien dalam pelayanan dan keamanan perawat dalam memberikan asuhan keperawatan, sebagai informasi statistik acuan perencanaan kebutuhan sarana prasarana dan sumber daya manusia di masa mendatang, sebagai sarana pendidikan yang dapat dijadikan media belajar bagi mahasiswa dan bahan penelitian dalam pengembangan ilmu keperawatan, sebagai sumber data dalam audit keperawatan untuk alat ukur dalam penilaian kinerja perawatan, sebagai dokumen yang bisa dijadikan aspek legal dan bukti autentik bagi perawat ketika menghadapi masalah hukum, sebagai jaminan kualitas pelayanan kesehatan dan pelayanan keperawatan (Setiadi,2012).

Undang-Undang RI Nomor 44 Tahun 2009 tentang Rumah Sakit Pasal 52 menyatakan bahwa setiap rumah sakit wajib melakukan pencatatan dan pelaporan semua penyelenggaraan kegiatan rumah sakit dalam bentuk sistim informasi manajemen berupa pencatatan, penyimpanan, pelaporan dan pemusnahan dalam waktu tertentu sesuai peraturan perundang-undangan.

Rumah sakit dalam pengelolaannya mempunyai pilar yang saling terkait satu sama lain yaitu: administrasi, manajemen berupa perencanaan setiap kegiatan, disiplin dari pelakunya, leadership dan kepemimpinan diri. Teori menyatakan "tulis apa yang ingin dilakukan, lakukan apa yang telah ditulis dan tulis apa yang telah dilakukan". Pelayanan yang diselenggarakan rumah sakit ada dua jenis yaitu pelayanan kesehatan dan administratif. Salah satu bentuk pelayanan 
kesehatan adalah pelayanan di poliklinik gigi berupa promotif, preventif, kuratif, rehabilitatif. Pelayanan administratif salah satunya adalah dokumentasi keperawatan yang berisi catatan keperawatan sebagai bukti pelaksanaan proses keperawatan dan catatan tanggapan/respon klien terhadap tindakan medis dan tindakan keperawatan yang telah dilaksanakan.

Dokumentasi keperawatan terdiri dari 1) keterampilan berkomunikasi untuk pengumpulan data dan menciptakan hubungan baik antara perawat dan klien dalam pemecahan masalah klien. 2) dokumentasi proses keperawatan yang merupakan metode pemecahan masalah secara sistimatis sesuai kaidah keperawatan dan 3) standar dokumentasi dapat memberi informasi pernyataan kualitas dan kuantitas dokumentasi untuk memperkuat pola pendokumentasian keperawatan.

Tahap-Tahap

Pendokumentasian Asuhan Keperawatan

1. Dokumentasi Pengkajian Asuhan Keperawatan

Pengkajian adalah tahap awal dari proses keperawatan dan merupakan proses suatu pengumpulan data yang sistematis dari berbagai sumber untuk mengevaluasi dan mengidentifikasi status kesehatan klien (Lyer et al,1996). Menurut Nursalam (2011), kriteria pengkajian keperawatan meliputi :
1. Pengumpulan data

a. Tipe data

Tipe data pada pengkajian keperawatan terdiri dari data subjektif dan data objektif. Data subjektif adalah data yang didapatkan dari klien /pasien sebagai suatu pendapat terhadap suatu situasi dan kejadian, data objektif adalah data yang diobservasi dan diukur oleh perawat.

b. Fokus pengambilan data

Fokus pengambilan data meliputi riwayat status kesehatan sebelumnya dan saat ini, pola koping yang pernah digunakan dan yang saat ini digunakan, fungsi, status sebelumnya dan saat ini, respon terhadap terapi medis dan intervensi keperawatan, resiko untuk masalah potensial hal-hal yang dapat menjadi dorongan atau kekuatan bagi klien.

2. Karakteristik Data

Data yang dikumpulkan untuk menunjang diagnosa keperawatan harus mempunyai karakteristik yang lengkap, akurat, nyata dan relevan.

\section{Sumber Data}

Data-data yang dikumpulkan dapat diperoleh tidak hanya dari klien tetapi dari orang terdekat (keluarga), catatan klien, riwayat penyakit terdahulu, konsultasi dengan terapi, hasil pemeriksaan diagnostik, catatan medis, dan sumber kepustakaan. 
2. Dokumentasi Diagnosa

Keperawatan

Diagnosa asuhan keperawatan adalah pernyataan yang menjelaskan status atau masalah kesehatan aktual atau potensial serta penyebabnya (Nursalam,2007). Tahap diagnosa adalah tahap pengambilan keputusan pada proses keperawatan yang meliputi identifikasi apakah maslah klien dapt dihilangkan , dikurangi atau diubah melalui tindakan keperawatan (Nursalam,2007). Kriteria proses keperawatan meliputi : proses diagnosa terdiri dari atas analisis, interprestasi data, identifikasi masalah, klien dan perumusan diagnosis keperawatan, diagnosa keperawatan terdiri dari atas masalah, penyebab, dan tanda atau gejala, atau terdiri atas masalah dan penyebab, bekerjasama dengan klien, petugas kesehatan lain untuk memvalidasi diagnosa keperawatan, melakukan pengkajian ulang, dan merevisi diagnosa berdasarkan data terbaru (Nursalam2007).

\section{Dokumentasi Rencana}

Keperawatan

Tujuan perencanaan intervensi keperawatan dan aktivitas keperawatan untuk mengurangi, menghilangkan, dan mencegah masalah keperawatan klien. Kriteria proses perawatan membuat rencana tindakan asuhan keperawatan untuk mengatasi masalah dan meningkatkan kesehatan meliputi perencanaan terdiri atas prioritas, tujuan dan rencana tindakan keperawatan, bekerjasama dengan klien dalam menyusun rencana tindakan keperawatan, perencanaan bersifat individual sesuai dengan kondisi atau kebutuhan klien, mendokumentasikan rencana keperawatan (Nursalam,2007).

Tujuan rencana asuhan keperawatan yaitu tujuan administrasi meliputi mengidentifikasi fokus keperawatan individu atau keluarga, membedakan tanggung jawab perawat dengan profesi kesehatan lainnya, menyusun kriteria guna pengulangan asuhan keperawatan dan evaluasi, keberhasilan asuhan keperawatan, menyediakan kriteria klasifikasi klien, sedangkan tujuan klinik meliputi suatu pedoman dalam penulisan, mengkomunikasikan asuhan keperawatan yang akan diimplememtasikan dengan perawat lain seperti apa yang akan diajarkan, apa yang harus diobservasi, apa yang akan dilakukan.

4. Dokumentasi Implementasi Keperawatan

Implementasi adalah pelaksanaan dari rencana intervensi untuk mencapai tujuan yang spesifik yaitu membantu klien dalam mencapai tujuan yang telah ditetapkan mencakup peningkatan kesehatan, pencegahan penyakit, 
pemulihan kesehatan dan mempasilitasi koping (Lyer et al,1999). Kriteria pengimplementasian tindakan yang telah diidentifikasi dalam rencana asuhan keperawatan meliputi bekerjasama dengan klien dalam pelaksanaan tindakan keperawatan, kolaborasi dengan tim kesehatan lain, melekukan tindakan keperawatan untuk mengatasi kesehatan klien, memberikan pendidikan pada klien dan keluarga mengenai konsep ketrampilan asuhan diri serta membantu klien memodifikasi lengkunganyang digunakan, mengkaji ulang dan merevisi pelaksanaan tidakan keperawatan berdasarkan respon klien (Nursalam 2007).

\section{Dokumentasi Evaluasi}

Keperawatan

Evaluasi asuhan keperawatan merupakan fase akhir dari proses keperawatan. Hal-hal yang dievaluasikan adalah keakuratan, kelengkapan, kualitas data, teratasi atau tidaknya masalah klien, dan pencapaian tujuan serta ketepatan intervensi keperawatan (Nursalam,2007) Kriteria perawat mengevaluasi kemajuan klien terhadap tindakan keperawatan dalam pencapaian tujuan, dan merevisi data dasar dan perencanaan meliputi menyusun perencanaan evaluasi hasil dari intervensi secara komprehensif, tepat waktu dan terus menerus, menggunakan data dasar dan respon klien dalam mengukur perkembangan kearah pencapaian tujuan, memvalidasi dan menganalisis data baru dengan teman sejawat, bekerjasama dengan klien, keluarga untuk memodifikasi rencana asuhan keperawatan, mendokumentasikan hasil evaluasi dan memodifikasikan perencanaan (Nursalam,2007).

\section{PENUTUP}

Pendokumentasian asuhan keperawatan dapat digunakan sebagai tanggung jawab dan tanggung gugat dari berbagai kemungkinan masalah yang dialami oleh pasien atau klien baik masalah kepuasan maupun ketidak puasan terhadap pelayanan kesehatan yang diberikan (Nursalam,2001).

$$
\text { Pedokumentasian }
$$

asuhan keperawatan yang tepat waktu, akurat dan lengkap tidak hanya penting untuk melindungi perawat tetapi penting juga untuk membantu pasien atau klien mendapat asuhan keperawatan yang lebih baik (Depkes RI,1996). Pelaksanaan dokumentasi keperawatan sebagai salah satu alat ukur untuk mengetahui, memantau dan menyimpulkan suatu pelayanan asuhan keperawatan yang diselenggarakan di rumah sakit (Fisbach,1991 dalam Setiadi,2012). 
DAFTAR PUSTAKA

Dalami, E. (2011). Dokumentasi

Keperawatan Dengan Kurikulum

Berbasis Kompetensi. Jakarta :

Trans Info Media

Dewan Pengurus Pusat Persatuan Perawat

Nasional Indonesia. (2019).

Pedoman Penelitian Keperawatan

Indonesia Peraturan Menteri

Kesehatan Republik Indonesia

Nomor 82. (2013). Sistem

Informasi Manajemen Rumah Sakit

Hariyati, R. T. S. (2012). Optimalisasi

Kinerja Sistem Informasi

Manajemen Keperawatan Berbasis

Model Simpro. (Unpublished

doctoral dissertation

thesis). Universita Indonesia

Jakarta.

Riyadi, S. (2010). Keperawatan

Professional. Yogyakarta :Gosyen

Rosmalia. Dewi. (2015). Analisis Sistim

Manajemen

Dokumentasi

Keperawatan pada Poliklinik Gigi

Rumah Sakit di Bukittinggi. Jurnal

Kesehatan Andalas. 2015; 4(3

Sartika, Dewi; Hariyati, Tutik Sri;

Noviestasari, E. (2014). Self

Efficacy Perawat Dalam

Penggunaan Sistem Informasi

Keperawatan Di Rsia Bunda

Jakarta: Studi Fenomenologi.
Jurnal Keperawatan Indonesia, Volume 17

Setiadi. (2012). Konsep \& Penulisan

Dokumentasi AsuhanKeperawatan;

Teori dan Praktik. Yogyakarta

Grahallmu

Simamora, R. (2009). Dokumentasi Proses Keperawatan.

Simamora, R. H., Purba, J. M., Bukit, E.

K., \& Nurbaiti, N. (2019).

Penguatan Peran Perawat Dalam

Pelaksanaan Asuhan Keperawatan

Melalui Pelatihan Layanan Prima.

JPPM (Jurnal Pengabdian Dan

Pemberdayaan Masyarakat), 3(1), 25-31.

Susanto, Rachmat. (2010). Penerapan

Standar Proses Keperawatan Di

Puskesmas Rawat Inap Cilacap.

Jurnal Keperawatan Soedirman

(The Soedirman Journal of

Nursing). 5(2),80- 84.

Tarigan. Rosari, Handiyani. Hanni. 2019.

Manfaat Implementasi

Dokumentasi Asuhan Keperawatan

Berbasis Komputerisasi dalam

Meningkatkan Mutu Asuhan

Keperawatan. Jurnal Ilmiah

Kesehatan Pencerah, 08 (2), 2019,

110-116

Rosmalia. Dewi. (2015). Analisis Sistim

Manajemen Dokumentasi

Keperawatan pada Poliklinik Gigi 
Rumah Sakit di Bukittinggi. Jurnal

Kesehatan Andalas. 2015; 4(3) 